\title{
Soilless Media and Containers for Greenhouse Production of 'Galia' Type Muskmelon
}

\author{
J.C. Rodriguez ${ }^{1}$, D.J. Cantliffe, ${ }^{2,5}$, and N.L. Shaw ${ }^{3}$ \\ University of Florida, Institute of Food and Agricultural Sciences, \\ Horticultural Sciences Department, 1249 Fifield Hall, PO Box 110690, \\ Gainesville, FL 32611
}

\section{Z. Karchi ${ }^{4}$ \\ 74 Hashkedim Street, Kiryat-Tivon, Israel 36501}

Additional index words. Cucumis melo, protected agriculture, perlite, pine bark, specialty melon, polyethylene bag, plastic pot, economics

\begin{abstract}
In the spring of 2001 and 2002, different combinations of media (coarse perlite, medium perlite, and pine bark) and containers (polyethylene bags and plastic pots) were used for hydroponic production of 'Galia' muskmelons (Cucumis melo L.) to determine their effect on fruit yield and quality, and their influence on costs of production. Marketable yields obtained for 'Gal-152' in the spring 2001 and 2002 were $25.5 \mathrm{~kg} \cdot \mathrm{m}^{-2}$ and $39.0 \mathrm{~kg} \cdot \mathrm{m}^{-2}$ respectively. When data were combined for 2001 and 2002 , fruit yield and fruit quality were unaffected by any combination of media and container. Average soluble solids content was generally greater than $10^{\circ}$ Brix. It was determined that the use of pine bark media and plastic pots instead of perlite and bags would save $\$ \mathbf{1 8 , 2 0 0}$ per year (two crops) - a feasible option for reducing costs of producing 'Galia' muskmelons in greenhouses using soilless culture without loss of yield and fruit quality.
\end{abstract}

Soilless culture in greenhouses may be an alternative to traditional field production for high-value vegetable crops (Blank, 1999; Cantliffe et al., 2001; Pardossi et al., 2002; Schröder, 1999). Production of new crops, such as 'Galia' and 'Galia'-type muskmelons (Cucumis melo L.), using soilless cultivation practices could be an alternative crop for both new and existing greenhouse growers in Florida and the southeastern United States. High-value crops, currently marketed throughout Europe, such as 'Galia' muskmelon and Beit Alpha cucumber (Cucumis sativus L.), could open new markets for greenhouse growers (Cantliffe et al., 2001; Shaw et al., 2000) and give consumers in the United States the choice of new, high-quality commodities.

Commercial production of greenhouse vegetables with soilless media was adopted in part to reduce economic losses incited by soil-borne pathogens (Gullino and Garibaldi, 1994; Louvet, 1982; Riviere and Caron, 2001). Major advantages of protected soilless culture include reduced chemical use, especially methyl bromide, extending the harvest period, and the potential to increase yields by three to 10 times compared with those ob-

Received for publication 16 Feb. 2006. Accepted for publication 28 May 2006.

${ }^{1}$ Graduate student.

${ }^{2,5}$ Chair/professor.

${ }^{3} \mathrm{Sr}$. biological scientist.

${ }^{4}$ Plant breeder.

${ }^{5}$ To who reprint requests should be addressed; e-maildjc@ifas.ufl.edu. tained under field conditions (Cantliffe and Vansickle, 2001). Compared with traditional production methods, soilless culture can provide more efficient use of fertilizers and water (Jensen, 1997; Schwarz, 1995), reduce root diseases (Reed, 1996) and facilitate cultivation of crops in areas where normal field production would not be possible (Jensen, 1999).

The use of soilless culture has increased significantly in recent years (Garzo et al., 2002; Grillas et al., 2001). In Holland, various greenhouse vegetable crops such as tomato, pepper, and cucumber are produced mainly in rockwool (10,000 ha) (Hassall and Associates, Ltd., 2001). In Spain, only about $10 \%$ of the greenhouse industry is soilless (perlite and rockwool) whereas about $90 \%$ of the industry $(40,000 \mathrm{ha})$ is still produced using an artificial sandy soil called enarenado (Costa and Heuvelink, 2000). In the United States, rockwool and perlite are the most common soilless media types (Brentlinger, 1999; Schwarz, 1995), and in Florida, $76.4 \%$ of the total greenhouse area uses horticultural perlite (38 ha) (Tyson et al., 2001).

Although the nutrient film technique could be used to produce muskmelons, yields and overall plant growth could be reduced by the incidence of problems such as root death and disease (Pardossi et al., 1994, 2000, 2002). Rockwool may also be used to produce melons (Fukuda and Anami, 2002; Guler et al., 1995), but costs may be higher than other materials and in some countries, such as the United States, the use of rockwool has decreased as a result of the difficulty of its disposal (Böhme, 1995; Schwarz, 1995).
Horticultural grade or coarse perlite is also commonly used to produce greenhouse crops (Grillas et al., 2001; Tyson et al., 2001). Media characteristics can be measured by particle size, $\mathrm{pH}$, and electrical conductivity (EC). Different grades of perlite available for commercial use in Florida have been reported to have no negative effect on yield of certain horticultural crops (including melons) produced in northern Europe and the United States (Cantliffe et al., 2003; Orozco et al., 1995; Verdonk, 1983). Nonetheless, locally available substrates with reduced transportation and manufacture costs (e.g., pine bark) can produce equal or better yields than other traditional soilless substrates (Benoit and Ceustermans, 1995; Maloupa et al., 2001; Schnitzler and Heuberger, 2001; Shaw et al., 2004a,b).

Organic substrates such as sphagnum peat, wood fiber, and pine bark have been used to grow greenhouse crops such as Beit Alpha cucumbers and 'Galia' muskmelons (Cotter, 1974; Gruda et al., 2001; McGrady and Cotter, 1989; Shaw et al., 2004a,b; Starck and Oswiecimski, 1985). (Segura and colleagues 1998) indicated that media composed of black sedge peat or a mixture of sphagnum peat and black sedge peat for production of 'Galia' muskmelons had limited water-holding capacity but good aeration. Despite reports that suggest peat may be used to produce various vegetables successfully, new environmental concerns on the manufacture and use of peat in countries such as Canada, and the general escalated costs of peat (Adams et al., 1989; Wilson et al., 2001) have forced growers to consider alternatives. Although good results have been obtained for growing vegetable and ornamental crops with bark sources (Cantliffe et al., 2003; Shaw et al., 2004a; Wilson, 1984), phytotoxicity from phenolic compounds may be a concern (Politycka et al., 1985; Worrall, 1978).

Equally important for the production of crops in soilless media is the container used (Artetxe et al., 1997). The container not only has an effect on plant development, but also on production costs and cultural practices. Polyethylene bags are commonly used in Florida to produce various greenhouse crops (Tyson et al., 2001). These bags are filled with soilless media and are sealed or tied at their ends to prevent spills. Because typically two or more plants may be planted in the same bag, the spread of root diseases is more likely than in containers with single plants. Plastic pots $(11.3 \mathrm{~L}$ and $18.8 \mathrm{~L})$ generally have one plant per pot. In some areas of the United States, polyethylene bags filled with media are used for one or two crops or before they are discarded. In Florida, high solar radiation and high greenhouse temperatures degrade the plastic and cause them to deteriorate faster than in more northern areas. Photodegradation makes it nearly impossible for growers to use the bags for more than one cropping cycle. Melons in Florida are grown on two cropping cycles per year.

Until the mid 1990s, there was little information about soilless cultivation of melons, particularly 'Galia' (Schiavi et al., 1995). 
(Waldo and associates 1998) reported that soilless culture could be used to grow 'Galia' muskmelons successfully in North Central Florida using walk-in or low tunnels. When perlite was used to grow 'Galia' in walk-in tunnels, yields were $70 \mathrm{t} \cdot \mathrm{ha}^{-1}$; however, when perlite was used in a low tunnel, yields were $104 \mathrm{t} \cdot \mathrm{ha}^{-1}$ (Waldo et al., 1998). These yields were higher than those reported in Israel, where muskmelons are mostly grown in soil. Muskmelon production of 'Galia' and 'Galia'type fruits in the Newe Ya'ar and Arava deserts are about $44.2 \mathrm{t} \cdot \mathrm{ha}^{-1}$ and $53.9 \mathrm{t} \cdot \mathrm{ha}^{-1}$ respectively (Hecht, 1998). In Israel, these yields are obtained when production of three to five fruits per plant occurs and the average fruit weight is between $1.0 \mathrm{~kg}$ and $1.3 \mathrm{~kg}$ (Karchi, pers. comm.). Elsewhere, other muskmelon types produced in perlite and other soilless media have had higher yields than plants produced in sand or soil under open field conditions (Guler et al., 1995; Kim and Kim, 2002; Schiavi et al., 1995); however, under adequate management practices and environmental conditions, very little difference in yield and quality could be attributed to the type of soilless medium used (Guler et al., 1995; Raja Harun et al., 1991).

The objective of the current research was to determine whether high-yielding, highquality 'Galia' muskmelons could be produced in less expensive, recyclable media such as pine bark using long-lasting, durable plastic pots.

\section{Materials and Methods}

A preliminary experiment was conducted in the spring of 2000 ( 3 Feb. to 7 June 2000) using the muskmelon hybrid 'Galia' (Hazera Seeds Ltd., Grover Beach, Calif.). The research was located at the Protected Agriculture Project site at the Horticulture Research Unit in Gainesville, Fla. The greenhouse design was a $270-\mathrm{m}^{2}$ single-bay house with a double-layer polyethylene roof (Atlas Greenhouse Systems Inc., Alapaha, Ga.). The greenhouse was cooled through passive air movement achieved through side walls with lateral curtains $(1.20 \mathrm{~m})$, electric fans, and a roof ridge vent. The $1-\mathrm{m}$ roof vent was located $4 \mathrm{~m}$ high. A thermostat (Dayton Electric Mfg. Co., Niles, Ill.) controlled the opening of the ridge vent when inside air temperature reached $25{ }^{\circ} \mathrm{C}$. Air inside the greenhouse was circulated using four fans ( 60 $\mathrm{cm}$ in diameter; Dayton Electric Mfg. Co.) when temperature reached $28{ }^{\circ} \mathrm{C}$ at plant height. The side wall curtains could be closed manually when temperatures dropped below $16{ }^{\circ} \mathrm{C}$ or opened when they reached $28{ }^{\circ} \mathrm{C}$. Insect screen, $0.6 \mathrm{~mm}$ (50-mesh) (Klaymen Meteor Ltd., Petah-Tikva, Israel) covered the side walls and ridge vent. The insect screen restricted the entrance of insect pests as well as kept beneficial insects and natural predators inside the greenhouse.

Plants were trellised and pruned according to Shaw et al. (2001). Because of the height of the greenhouse in the spring of
2000 , the steel cable of the trellis system was set at $2.1 \mathrm{~m}$ from the ground. It was determined that the trellis system was too short for 'Galia' melon production because the plants quickly grew to the top of the trellis and needed to be draped over the top to grow down the opposite side. By draping the plants over the cable, it created a dense canopy where much of the plant was shaded. Also, air movement through the plant canopy was poor as seen by the moisture that became trapped between leaves and could not evaporate. The dense plant canopy also harbored pests and disease, making pest management efforts difficult. 'Galia' muskmelon plants should be trellised in a single-column fashion to create better light interception and air circulation throughout the plant canopy. To achieve a single-column growth structure, a high-roof passively ventilated greenhouse was constructed and used for the experiments in the spring of 2001 and 2002 where the trellis cable was $4 \mathrm{~m}$ from the ground.

The 'Galia'-type cultivar 'Gal-152' (Hazera Seeds Ltd.) was used for the experiments in the spring of 2001 (14 Feb. to 25 June 2001) and 2002 (18 Feb. to 12 July 2002). The replacement of 'Galia' with 'Gal-152' was done because it was found to be more tolerant to the diseases gummy stem blight and powdery mildew, also had larger fruit size as well (Shaw et al., 2001). The disease tolerance of the Gal-152 cultivar allowed for better implementation of biological pest management strategies. Furthermore, the larger fruit size of 'Gal-152' (1.2-1.8 kg) is more common for muskmelon in the U.S. market than that of the hybrid 'Galia' found throughout Israel and European markets $(0.5-0.9 \mathrm{~kg})$; but regardless of fruit size, the average number of fruits produced per plant (four fruits per plant) were similar for both cultivars (Shaw et al., 2001).

In the spring of 2001 and 2002, the experiments were conducted in a $7300-\mathrm{m}^{2}$ passively ventilated high-roof greenhouse (Top Greenhouses Ltd., Barkan, Israel) also located at the Protected Agriculture Project in Gainesville, Fla. The sawtooth design roof was covered with double-layer polyethylene plastic $(0.150 \mathrm{~mm}$ thick; Ginegar Plastic Products Ltd., Kibbutz Ginegar, Israel). Roof height was $8 \mathrm{~m}$ with a $1-\mathrm{m}$ ridge vent at the center of each bay. The side walls $(3.6 \mathrm{~m})$ were raised or lowered to provide additional air movement when the temperature rose above $28{ }^{\circ} \mathrm{C}$ or was expected to fall below $16{ }^{\circ} \mathrm{C}$. Side walls and roof vents were also covered with insect screen.

For all three experiments, seeds were sown in polystyrene flats (Speedling, Bushnell, Fla.) with cell sizes of $2.25 \mathrm{~cm}^{2}$ and 164 cells per flat, and produced inside an evaporative-cooled fan and pad glasshouse in Gainesville, Fla. A mixture (volume/volume) of $70 \%$ Terra Lite Plug Mix (Terra Asgrow, Apopka, Fla.) and 30\% coarse vermiculite was used as the growing medium. Temperatures of $28^{\circ} \mathrm{C}$ day and $22^{\circ} \mathrm{C}$ night, as well as a daily $12-\mathrm{h}$ artificial light supplement, were maintained for optimal seedling growth.
Seeds of 'Galia' were sown on 5 Jan. 2000 and 'Gal-152' seeds were sown on 25 Jan. 2001 and 22 Jan. 2002. After emergence and after the cotyledons were fully expanded, seedlings were fertilized twice a week using a $20 \mathrm{~N}-8.8 \mathrm{P}-16 \mathrm{~K}$ soluble fertilizer (Spectrum Group, St. Louis, Mo.) to provide $50 \mathrm{mg} \cdot \mathrm{L}^{-1} \mathrm{~N}, 23 \mathrm{mg} \cdot \mathrm{L}^{-1} \mathrm{P}$, and $44 \mathrm{mg} \cdot \mathrm{L}^{-1}$ $\mathrm{K}$, as well as other essential nutrients $(\mathrm{Mg}$, $5 \mathrm{mg} \cdot \mathrm{L}^{-1} ; \mathrm{B}, 0.2 \mathrm{mg} \cdot \mathrm{L}^{-1} ; \mathrm{Cu}, 0.5 \mathrm{mg} \cdot \mathrm{L}^{-1} ; \mathrm{Fe}$, $0.1 \mathrm{mg} \cdot \mathrm{L}^{-1} ; \mathrm{Mn}, 0.5 \mathrm{mg} \cdot \mathrm{L}^{-1}$; Mo, 0.005 $\mathrm{mg} \cdot \mathrm{L}^{-1}$; and $\mathrm{Zn}, 0.005 \mathrm{mg} \cdot \mathrm{L}^{-1}$ ). Plants were transplanted with three or four fully expanded leaves.

All experiments were a randomized complete block design with four blocks. Plant spacing was $0.30 \mathrm{~m}$ between plants and $1.2 \mathrm{~m}$ between rows. Two types of containers were used: 36.0-L polyethylene bags (Agrodynamics, East Brunswick, N.J.) and 11.3-L black plastic nursery pots (Lerio Co., Kissimmee, Fla.). Three types of media were used: coarse perlite, medium perlite (Airlite Processing Corporation of Florida, Vero Beach, Fla.), and pine bark (Elixon Wood Products, Starke, Fla.). The factorial combination of container and media resulted in six treatments: coarse perlite bag, coarse perlite pot, medium perlite bag, medium perlite pot, pine bark bag, and pine bark pot. Medium perlite was not available in spring 2000 , thus only coarse perlite and pine bark were evaluated. Each plot consisted of nine plants. Bags were planted with three plants each and pots contained one plant. Drainage slits below each plant in the bag were cut so excess solution could leach out and four $1.5-\mathrm{cm}$ holes were drilled equidistant $3 \mathrm{~cm}$ from the bottom of the pots for drainage and to create a reservoir. Costs of the various media will be described based on unit area of production.

The physical properties of the three media varied. The particle size for coarse perlite was 1.3 to $5.1 \mathrm{~mm}$, whereas medium perlite ranged from less than 0.25 to $2.4 \mathrm{~mm}$. Pine bark varied the greatest in particle size: $18 \%$ of the media volume was less than $0.25 \mathrm{~mm}$ whereas $52 \%$ of the volume ranged from 3.2 to $12.8 \mathrm{~mm}$ (Cantliffe et al., 2002). Moisture capacity of both coarse perlite and pine bark was nearly one-half that of medium perlite, $17 \%$ compared with $46 \%$. Air porosity was also similar for coarse perlite and pine bark at $40.6 \%$ and $46.7 \%$ respectively, whereas medium perlite measured $17 \%$ air porosity. Coarse and medium perlite both had a neutral $\mathrm{pH}$ of 7.0 whereas pine bark was acidic at 5.2. $\mathrm{EC}$ was similar for each medium at less than $0.06 \mathrm{dS} \cdot \mathrm{m}^{-1}$ (Cantliffe et al., 2003).

A pressure-compensated drip irrigation system (1.9 L $\cdot \mathrm{h}^{-1}$; Netafim USA, Longwood, Fla.) was used. Daily irrigation events were scheduled using an irrigation timer (Pro Rain; Antelco Corporation, Longwood, Fla.; Superior Controls Co., Valencia, Calif.) to allow $20 \%$ to $30 \%$ leachate of the total irrigation volume per plant per day ( $24 \mathrm{~h})$. The nutrient solution was proportioned using two waterdriven injectors (model Dosatron DI 16; Dosatron International, Clearwater, Fla.) and delivered to the plants through the drip 
system each time the plants were irrigated. All treatments were irrigated and fertilized equally. The plants received $120 \mathrm{mg} \cdot \mathrm{L}^{-1} \mathrm{~N}$ during the first 2 weeks after transplanting (Table 1). The concentration was increased to $160 \mathrm{mg} \cdot \mathrm{L}^{-1} \mathrm{~N}$ during the third week and gradually raised to $200 \mathrm{mg} \cdot \mathrm{L}^{-1} \mathrm{~N}$ from flowering to fruit maturation. The concentration of $200 \mathrm{mg} \cdot \mathrm{L}^{-1} \mathrm{~N}$ was lowered to 170 $\mathrm{mg} \cdot \mathrm{L}^{-1} \mathrm{~N}$ when the fruits began to turn color and was maintained until the end of the season. This practice of alternating $\mathrm{N}$ levels was based on suggested recommendations of traditional field cultural practices for cultivation of 'Galia' muskmelons (Zvi Karchi pers. comm.; Hecht, 1998).

A hive with 35 to 40 bumble bees (Bombus impatiens; Natupol, Koppert Biological Systems, Ann Arbor, Mich.) was placed for pollination on the south end section of the crop as female flowers opened during the third or fourth week after transplanting. During the three growing seasons, mild to severe outbreaks of arthropod pests were encountered. In spring 2000, two-spotted spider mites (Tetranychus urticae) were detected when the plants were about 7 weeks old. Because bumble bees were being used for pollination, predatory mites (Neoselius californicus, IPM Laboratories, Inc., Locke, N.Y.) were released as a biological control. Two separate applications (10 d apart) of $\sim 15$ to 20 predatory mites were released directly on individual plants where the spider mites were found. Full control was not achieved within 2 weeks and spider mite populations continued to increase. At 2 and 3 weeks after the last release of predatory mites, one application of Agrimek (Abemectin; Novartis Crop Protection, Greensboro, N.C.) and one application of Kelthane (Difocol; Rohm \& Haas Co., Philadelphia, Pa.) were made to eliminate spider mite pests. Bees were removed during application and were reentered after a recommended time

Table 1. Final delivered concentrations (measured in milligrams per liter) of essential elements for 'Galia' muskmelons cultivated in soilless media at different stages of growth expressed as weeks after transplant (WAT).

\begin{tabular}{lrrrr}
\hline \multirow{2}{*}{$\begin{array}{l}\text { Essential } \\
\text { element }\end{array}$} & \multicolumn{4}{c}{ Plant growth stage } \\
\cline { 2 - 5 } $\mathrm{N}$ & 1 & 2 & 3 & 4 \\
\hline $\mathrm{P}$ & 120 & 160 & 200 & 170 \\
$\mathrm{~K}$ & 50 & 50 & 50 & 50 \\
$\mathrm{Ca}$ & 113 & 135 & 165 & 135 \\
$\mathrm{Mg}$ & 134 & 134 & 152 & 134 \\
$\mathrm{~S}$ & 40 & 40 & 40 & 40 \\
$\mathrm{Cu}$ & 65 & 65 & 65 & 65 \\
$\mathrm{Zn}$ & 0.2 & 0.2 & 0.2 & 0.2 \\
$\mathrm{Mn}$ & 0.3 & 0.3 & 0.3 & 0.3 \\
$\mathrm{~B}$ & 0.8 & 0.8 & 0.8 & 0.8 \\
$\mathrm{Mo}$ & 0.7 & 0.7 & 0.7 & 0.7 \\
$\mathrm{Fe}$ & 0.06 & 0.06 & 0.06 & 0.06 \\
\hline
\end{tabular}

${ }^{\mathrm{z}}$ Growth stage 1 (0-2 WAT), transplant to plant establishment; growth stage 2 (2-4.5 WAT), vegetative growth to flower initiation; growth stage 3 (4.5-9 WAT), flower initiation to fruit set and maturation; growth stage 4 (9-20 WAT), fruit maturation to harvest and termination. period of at least $36 \mathrm{~h}$ (Koppert Biological Systems). fully implemented in 2001 and 2002. Pest management included weekly monitoring of pests in the crop and preventive weekly releases of generalist beneficial insects. Aphids (Myzus persicae and Aphis gossypii) were controlled with adult lady beetles (Hippodamia convergens; IPM Laboratories, Inc.) and three releases (every 2 weeks) of parasitic wasps (Aphidius colemani; IPM Laboratories, Inc.) and big-eye bugs (Geocoris punctipes; Entomos LLC, Gainesville, Fla.). Orius sp. (Entomos LLC) were used to control western flower thrips (Frankliniella occidentalis).

Plants were sprayed with Quadris (Azoxystrobin; Zeneca Agricultural Products, Wilmington, Del.) every $15 \mathrm{~d}$ for a total of three applications to control powdery mildew (Sphaeroteca fuliginea). Preventive applications of fungicides began 4 weeks after transplanting. Prevention and control of gummy stem blight (Didymella bryoniae) was accomplished using both Quadris and Bravo (Chlorothalonil; ISK Bioscience Corporation, Mentor, Ohio). Bravo was applied twice at 6 and 8 weeks after transplanting. Both powdery mildew and gummy stem blight were prevented in 2001 and 2002.

Mature fruits were harvested at the fullslip stage about three times per week beginning 12 weeks after transplanting from 3 May to 7 June 2000, 11 May to 25 June 2001, and 28 Apr. to 7 July 2002. Full slip occurred when the fruits had a golden yellow background color. There were 10 harvests in spring 2000, 16 in spring 2001, and 19 harvests in spring 2002. The spring 2000 experiment was ended early because of the outbreak of two-spotted spider mites. At each harvest, number of fruits per plant, fruit size, weight, and quality were recorded. Fruit were graded by weight into extra small $(0.5-0.69$ $\mathrm{kg})$, small $(0.7-0.99 \mathrm{~kg})$, medium (1.0-1.19 $\mathrm{kg})$, large $(1.20-1.49 \mathrm{~kg})$, and extra large $(>1.49 \mathrm{~kg})$ categories. Fruit quality was measured as soluble solids content (SSC) and was measured immediately at harvest using two $1-\mathrm{cm}$ cores taken from the flesh at the equator of each fruit. The direct extractant was analyzed for SSC using a hand-held refractometer and recorded as ${ }^{\circ} \mathrm{Brix}$ (AO
Integrated pest management was success-

10430, Warner-Lambert Technologies, Inc., N.H.).

Analysis of variance was performed to test for significant interactions between media and container and their effects on yield, fruit quality, and plant growth using SAS software (SAS, Cary, N.C.). When the interaction was not significant, means from the main effects of the two variables (media and container) were reported.

\section{Results and Discussion}

For the preliminary trial in spring 2000, no interactions were found between media and container for any variable, and no significant differences were found as a result of the type of media or container (data not reported). Averages of 4.1 fruits per plant were obtained for all treatments, for which average fruit weight was $0.7 \mathrm{~kg}$. Fruit width and length were $\sim 106 \mathrm{~mm}$ and $115 \mathrm{~mm}$ respectively. SSC was $10.9^{\circ}$ Brix regardless of media or container used. From this trial adjustment in cultivar, greenhouse structure and pest management were made.

In spring 2001, type of container had a significant effect on several yield variables (Table 2). Number of fruits per plant, fruit weight per plant, and marketable yield per unit area were greater in plants grown in pots than in bags. For every 10 plants, there were about two more fruits produced from plants grown in plastic pots than those grown in bags. Although media volume per plant was equal between pots and bags $(\sim 12 \mathrm{~L})$, there may have been competition for nutrients and water among the root systems of plants grown in bags compared with the individual plant root systems when grown in pots. There were no differences in the average weight of individual fruits grown in bags or pots $(1.7 \mathrm{~kg}$ each).

The type of media used had no effect on yield variables in spring 2001 (Table 2). Regardless of whether the plants grew in coarse perlite, medium perlite, or pine bark, yields per plant and per unit area as well as fruit quality were the same. Also, it should be noted that an average $25.5 \mathrm{~kg} \cdot \mathrm{m}^{-2}$ of marketable fruit was produced, well more than 2.5 times greater than yields previously reported by (Shaw and colleagues 2001).

Table 2. Means for total marketable yields and fruit quality parameters of 'Gal-152' muskmelons grown in different types of growing containers and soilless media in spring 2001.

\begin{tabular}{|c|c|c|c|c|c|c|c|}
\hline \multirow[b]{2}{*}{ Variable } & \multicolumn{4}{|c|}{ Fruit yield parameters } & \multicolumn{3}{|c|}{ Fruit quality parameters } \\
\hline & $\begin{array}{c}\text { No. of fruits } \\
\text { per plant }\end{array}$ & $\begin{array}{c}\text { Fruit } \\
\text { wt. }(\mathrm{kg})\end{array}$ & $\begin{array}{c}\text { Fruit wt. } \\
\text { per plant }(\mathrm{kg})\end{array}$ & $\begin{array}{c}\text { Marketable } \\
\text { yield }\left(\mathrm{kg} \cdot \mathrm{m}^{-2}\right)\end{array}$ & $\begin{array}{l}\text { Width } \\
(\mathrm{mm})\end{array}$ & $\begin{array}{l}\text { Length } \\
(\mathrm{mm})\end{array}$ & $\begin{array}{c}\text { Soluble } \\
\text { solids }\left({ }^{\circ} \text { Brix }\right)\end{array}$ \\
\hline \multicolumn{8}{|l|}{ Container } \\
\hline Bag & 4.7 & 1.7 & 7.7 & 25.3 & 130 & 139 & 10.4 \\
\hline Pot & 4.9 & 1.7 & 7.9 & 26.3 & 130 & 137 & 10.3 \\
\hline Significance ${ }^{z}$ & $*$ & NS & $*$ & $*$ & NS & NS & NS \\
\hline \multicolumn{8}{|l|}{ Media } \\
\hline Coarse perlite & 4.8 & 1.7 & 7.9 & 26.1 & 130 & 140 & 10.3 \\
\hline Medium perlite & 4.7 & 1.7 & 7.8 & 25.9 & 131 & 139 & 10.4 \\
\hline Pine bark & 4.7 & 1.7 & 7.7 & 25.7 & 129 & 139 & 10.3 \\
\hline Significance & NS & NS & NS & NS & NS & NS & NS \\
\hline Interaction & NS & NS & NS & NS & NS & NS & NS \\
\hline
\end{tabular}

Ns Nonsignificant, ${ }^{*}$ Significant at the $P=0.05$ level. 
Yields were greatest in the spring of 2002 (Table 3). No significant interactions occurred between media and container on fruit yield and quality. Regardless of whether plants grew in bags or pots, $\sim 7.1$ fruits per plant were obtained with an average fruit weight of $1.7 \mathrm{~kg}$ each. The average marketable yield was $39.1 \mathrm{~kg} \cdot \mathrm{m}^{-2}$. Plants grown in pine bark produced slightly smaller fruit (1.6 $\mathrm{kg}$ ) compared with those that grew in either coarse- or medium-grade perlite $(1.7 \mathrm{~kg})$. However, no differences were found resulting from the type of media for the average fruit weight per plant, marketable yield per unit area, or fruit quality. In contrast, experiments conducted at the same location using the same media as within this paper for Beit Alpha cucumber, determined that total marketable yields were greater when plants were grown in medium-grade perlite compared with coarse grade, but these yields were not significantly different from those from plants grown in pine bark (Shaw et al., 2004a). Regardless of the type of media or container used, SSC averaged $10.4{ }^{\circ}$ Brix. Yields in 2002 were $40 \%$ greater than the high yields of 2001 and were attributed to the overall health of the plants during 2002, which allowed 19 harvests compared with 16 in 2001.

Data were combined for 2001 and 2002 (Table 4). However, after data were combined, no differences were found for type of media or container for any yield variable. Although the interaction between season was not significant, differences were found resulting from container in spring 2001 and media in 2002 and therefore are presented in Tables 2 and 3 .

Plants may go through different physiological and morphological changes in response to growing space and type of media (Michel et al., 1999; NeSmith and Duval, 1998). In our work, all plants were planted at the same distance within and between the row, and the volume of media per plant was similar. The differences observed in individual seasons may have been influenced more by climatic factors and length of harvest period than by the type of container and medium that was used. Temperatures were somewhat lower in 2001 than 2002 (data not presented). Minimum temperature in the latter half of Apr. 2001 approached $5{ }^{\circ} \mathrm{C}$ on several nights, whereas minimum temperatures in 2002 never went below $15^{\circ} \mathrm{C}$.

Table 3. Means for total marketable yields and fruit quality parameters of 'Gal-152' muskmelons grown in different types of growing containers and soilless media in spring 2002.

\begin{tabular}{|c|c|c|c|c|c|c|c|}
\hline \multirow[b]{2}{*}{ Variable } & \multicolumn{4}{|c|}{ Fruit yield parameters } & \multicolumn{3}{|c|}{ Fruit quality parameters } \\
\hline & $\begin{array}{l}\text { No. of fruits } \\
\text { per plant }\end{array}$ & $\begin{array}{c}\text { Fruit } \\
\text { wt. (kg) }\end{array}$ & $\begin{array}{c}\text { Fruit wt. } \\
\text { per plant }(\mathrm{kg})\end{array}$ & $\begin{array}{c}\text { Marketable } \\
\text { yield }\left(\mathrm{kg} \cdot \mathrm{m}^{-2}\right)\end{array}$ & $\begin{array}{l}\text { Width } \\
(\mathrm{mm})\end{array}$ & $\begin{array}{l}\text { Length } \\
(\mathrm{mm})\end{array}$ & $\begin{array}{c}\text { Soluble } \\
\text { solids }\left({ }^{\circ} \text { Brix }\right.\end{array}$ \\
\hline \multicolumn{8}{|l|}{ Container } \\
\hline Bag & 7.1 & 1.7 & 11.8 & 39.0 & 128 & 137 & 10.3 \\
\hline Pot & 7.2 & 1.7 & 11.9 & 39.2 & 129 & 138 & 10.3 \\
\hline Significance $^{z}$ & NS & NS & NS & NS & NS & NS & NS \\
\hline \multicolumn{8}{|l|}{ Media } \\
\hline Coarse perlite & 7.1 & 1.7 & 12.0 & 39.7 & 128 & 135 & 10.4 \\
\hline Medium perlite & 7.2 & 1.7 & 12.0 & 39.6 & 127 & 136 & 10.5 \\
\hline Pine bark & 7.1 & 1.6 & 11.6 & 38.1 & 128 & 136 & 10.4 \\
\hline Significance & NS & $*$ & NS & NS & NS & NS & NS \\
\hline Interaction & NS & NS & NS & NS & NS & NS & NS \\
\hline
\end{tabular}

${ }^{\text {ss Nonsignificant. } * \text { Significant at the } P=0.05 \text { level. }}$

${ }^{\mathrm{N}}$ Nonsignificant.
Growth of 'Gal-152' muskmelon plants was not influenced by the type of media or container that was used during the spring of 2001 and 2002 (data not presented). During both years, plants reached the height of the trellis cable $\sim 4 \mathrm{~m}$ above the ground. Regardless of type of media or container, there were on average 54 leaves per plant.

Yields and fruit quality in spring 2001 and 2002 were better than previously reported results for either field and protected production of 'Galia' and 'Galia'-type muskmelons in Florida, where yields from 25 to $104 \mathrm{t} \cdot \mathrm{ha}^{-1}$ were obtained (Hochmuth et al., 1998; Waldo et al., 1998). Furthermore, in spring 2002, yields were not only greater than those in spring 2000 and 2001, but also greater than those of several reports of soilless and soilcultivated melons in Florida, Italy, and Israel (Hecht, 1998; Hochmuth et al., 1998; Pardossi et al., 1994; Schiavi et al., 1995; Waldo, 1999). Fruit weight in spring 2002 appeared to be the only yield trait affected by type of media. Fruits that grew in pine bark weighed $100 \mathrm{~g}$ less than those cultivated in coarse and medium perlite; however, this difference was not observed during the other growing seasons. 'Galia' was originally chosen for the experiment because of its superior fruit quality over other 'Galia'-type melons as determined by its higher Brix content (Shaw et al., 2001). However, the smaller fruit size obtained from 'Galia' $(0.7 \mathrm{~kg})$ is less desirable for the U.S. markets, where the larger size fruits such as those produced by 'Gal-152' $(1.7 \mathrm{~kg})$ is preferred.

Table 4. Combined means for total marketable yields and fruit quality parameters of 'Gal-152' muskmelon grown in different types of growing containers and soilless media in spring 2001 and 2002.

\begin{tabular}{|c|c|c|c|c|c|c|c|}
\hline \multirow[b]{2}{*}{ Variable } & \multicolumn{4}{|c|}{ Fruit yield parameters } & \multicolumn{3}{|c|}{ Fruit quality parameters } \\
\hline & $\begin{array}{l}\text { No. of fruits } \\
\text { per plant }\end{array}$ & $\begin{array}{c}\text { Fruit wt. } \\
\quad(\mathrm{kg})\end{array}$ & $\begin{array}{c}\text { Fruit wt. } \\
\text { per plant }(\mathrm{kg})\end{array}$ & $\begin{array}{c}\text { Marketable } \\
\text { yield }\left(\mathrm{kg} \cdot \mathrm{m}^{-2}\right)\end{array}$ & $\begin{array}{l}\text { Width } \\
\text { (mm) }\end{array}$ & $\begin{array}{l}\text { Length } \\
(\mathrm{mm})\end{array}$ & $\begin{array}{c}\text { Soluble } \\
\text { solids ( }{ }^{\circ} \text { Brix) }\end{array}$ \\
\hline \multicolumn{8}{|l|}{ Container } \\
\hline Bag & 5.9 & 1.6 & 9.7 & 32.2 & 128 & 132 & 10.4 \\
\hline Pot & 6.0 & 1.7 & 9.6 & 32.8 & 128 & 133 & 10.5 \\
\hline Significance ${ }^{z}$ & NS & NS & NS & NS & NS & NS & NS \\
\hline \multicolumn{8}{|l|}{ Media } \\
\hline Coarse perlite & 5.9 & 1.7 & 10.0 & 32.9 & 129 & 133 & 10.4 \\
\hline Medium perlite & 6.1 & 1.7 & 9.9 & 32.8 & 130 & 132 & 10.5 \\
\hline Pine bark & 5.9 & 1.6 & 9.6 & 31.8 & 133 & 133 & 10.5 \\
\hline Significance & NS & NS & NS & NS & NS & NS & NS \\
\hline Interaction & NS & NS & NS & NS & NS & NS & NS \\
\hline
\end{tabular}

Despite the various combinations of media and containers used in these experiments, fruit yield and quality, as well as overall plant growth of 'Galia'-type muskmelons were unaffected. Cantliffe et al. (2001) reported that greenhouse vegetables can be grown in various types of soilless media, as long as proper irrigation and fertilization is provided. Good productivity of greenhouse vegetable crops has been obtained with many commercially available media such as peat mixes, perlite, and pine bark (Böhme, 1995; Cantliffe et al., 2001; Maloupa et al., 2001). The use of soilless culture and passive-ventilated greenhouses in Florida is an alternative system for the production of high-value vegetable crops (Blank, 1999; Cantliffe et al., 2001; Schröder, 1999). Production of new crops such as 'Galia' and 'Galia'-type muskmelons using soilless culture practices could be implemented by existing greenhouse growers. The advantages of producing 'Galia'-type muskmelons using soilless media are not only high-quality fruit, but yields three times greater than those obtained under field conditions (Cantliffe and Vansickle, 2001; Shaw et al., 2001; Waldo, 1999).

Production costs must be considered before starting a greenhouse business. Because individual plants are grown in pots and three plants can be grown per bag, 3.3 pots and 1.3 bags are needed per square meter to equal the same plant density of 3.3 plants $\mathrm{m}^{-2}$ (Table 5). Each individual pot costs four times (\$1.00) more initially than each bag (\$0.25); however, plastic pots are more durable and could be used for 10 years $(20$ crop cycles) before they need to be replaced, thus reducing their cost per growing cycle. On the other hand, polyethylene bags break down easily and must be replaced after one or two growing cycles, lasting only 1 year or less under Florida's intense radiation. Based on total life of the container, both bags and pots cost the same: $\$ 0.33 \mathrm{~m}^{-2}$ year ${ }^{-1}$.

The price of media is another factor that could influence production costs and profit (Shaw et al., 2004a). When perlite and pine bark are purchased in bulk, perlite is five times more expensive than pine bark: $\$ 40 \mathrm{~m}^{-3}$ and $\$ 8 \mathrm{~m}^{-3}$ respectively (Table 5). Regardless of using bags or pots as containers, the initial cost of perlite used per square meter will remain 
Table 5. Estimate costs of container and media used for soilless greenhouse 'Galia' or 'Galia'-type muskmelon production.

\begin{tabular}{|c|c|c|c|c|c|}
\hline Container only & $\operatorname{Each}(\$)$ & $\operatorname{Cost}(\$) / \mathrm{m}^{2}$ & \multicolumn{3}{|c|}{ Cost of container $\mathrm{m}^{-2} \mathrm{y}^{-1}$ (based on life of container) } \\
\hline Bag & 0.25 & 0.33 & \multicolumn{2}{|c|}{$1 \mathrm{y}=\$ 0.33 \mathrm{y}^{-1}$} & \\
\hline Pot & 1.00 & 3.30 & \multicolumn{2}{|c|}{$10 y=\$ 0.33 y^{-1}$} & \\
\hline Media only & Cost of media $(\$) / \mathrm{m}^{3}$ & $\begin{array}{l}\text { Cost }(\$) \text { of } \\
\text { media/bag }\end{array}$ & $\begin{array}{l}\text { Cost of media } \\
\text { to fill bags }(\$) / \mathrm{m}^{2}\end{array}$ & Cost $(\$)$ of media/pot & $\begin{array}{l}\text { Cost of media to } \\
\left.\text { fill pots }(\$) / \mathrm{m}^{2}\right)\end{array}$ \\
\hline Perlite & 40.00 & 1.44 & 1.92 & 0.46 & 1.52 \\
\hline Pine bark & 8.00 & 0.29 & 0.39 & 0.09 & 0.30 \\
\hline Container + media & $\begin{array}{c}\text { Cost }(\$) / \mathrm{m}^{2} \text { if using bags } \\
\text { (initial) }\end{array}$ & $\begin{array}{c}\text { Cost }(\$) / \mathrm{m}^{2} \\
\text { if using } \\
\text { pots (initial) }\end{array}$ & $\begin{array}{c}\text { Cost }(\$) / \mathrm{m}^{2} \text { if in pots } \\
\text { (based on } 10-\mathrm{y} \text { life } \\
\text { of container) }\end{array}$ & $\begin{array}{l}\text { Cost (\$/ha) using } \\
\text { bags (with } 1-y \text { life) }\end{array}$ & $\begin{array}{c}\text { Cost ( } \$ / \text { ha) using pots } \\
\text { (based on life of } \\
\text { container) }\end{array}$ \\
\hline Perlite & 2.25 & 4.82 & 1.85 & 22,500 & 18,500 \\
\hline Pine bark & 0.72 & 3.60 & 0.63 & 7200 & 4300 \\
\hline
\end{tabular}

${ }^{2}$ Labor to remove used bags, and fill and place new bags every year (two crops) not included in cost estimates. Labor to remove pots, and empty and refill every 3 years (six crops) not included in cost estimates.

${ }^{\mathrm{y}}$ Cost for pots filled with perlite are based on using new perlite every year (two crops).

five times greater than when using pine bark. The cost (media only) to fill bags and pots with perlite media is $\$ 1.92$ and $\$ 1.52 \mathrm{~m}^{-2}$ respectively, compared with $\$ 0.39$ for bags and $\$ 0.30 \mathrm{~m}^{-2}$ for pots when using pine bark.

When the cost of the container is combined with the cost of the media, the initial cost of using pots is two and five times greater than using bags when filled with perlite and pine bark respectively (Table 5). However, if pots are depreciated over 10 years, significant reductions in costs occur and the use of pots becomes less expensive than the use of bags, regardless of media choice. When bags are replaced annually, generally new media will be used because removing and recycling the used media from the bag is labor intensive and the media becomes mixed with plant residues and trash. On the other hand, both pots and media remain in place inside the greenhouse when being reused (recycled). This can save a considerable sum on labor costs each season. Growers in South Florida currently use the same pots and pine bark for up to 3 years for colored pepper production (Shaw et al., 2004b); however, it is unknown whether perlite could be used for up to 3 years. Based on the life of the container (1 year for bags and 10 years for pots), the cost of using bags per hectare per year is $\$ 22,500$ when filled with perlite and $\$ 7200$ when filled with pine bark. The cost of using pots filled with pine bark is substantially less than bags filled with perlite at $\$ 4,300 \mathrm{ha}^{-1}$ year $^{-1}$ (pine bark media used for 3 years). The cost of using bags and perlite over 10 years is $\$ 182,000 \mathrm{ha}^{-1}$ more expensive than using pots filled with pine bark. Annual labor expenses to remove old bags, fill new bags, and replace them inside the greenhouse are not included in these calculations and may increase the cost of using bags over pots significantly, regardless of media used. Furthermore, perlite is difficult to discard for environmental reasons whereas spent pine bark can be repackaged and sold to the landscape and nursery industry, thus increasing the value of using pine bark media.

Florida may have a cost savings advantage over other states when using pine bark over perlite because there are several locations throughout the state that distribute the product. Other states, especially those in more northern climates with less intense sunlight than Florida, may be able to reuse bags for more than one crop. Because there was no effect on yield or fruit quality between the combinations of containers and media tested, our data support the recommendation to use pots filled with pine bark in the southeastern United States because of the economic savings.

\section{Literature Cited}

Adams, P., C.J. Graves, and G.W. Winsor. 1989. Some responses of cucumber, grown in beds of peat, to micronutrients and $\mathrm{pH}$. J. Hort. Sci. 64:293-299.

Artetxe, A., V. Terés, and A.I. Beunza. 1997. Effects of container size and substrates on hydrangea macrophilla growth. Acta Hort. 450:419-424.

Benoit, F. and N. Ceustermans. 1995. A decade of research on ecologically sound substrates. Acta Hort. 408:17-31.

Blank, C. 1999. Specialty process for specialty products. The Grower Magazine March:28-30.

Böhme, M. 1995. Evaluation of organic, synthetic and mineral substrates for hydroponically grown cucumbers. Acta Hort. 401:209-217.

Brentlinger, D. 1999. Status of the commercial hydroponic industry in the United States of America. Acta Hort. 481:731-734.

Cantliffe, D.J., J. Funes, E. Jovicich, A. Paranjpe, J. Rodriguez, and N. Shaw. 2003. Media and containers for greenhouse soilless grown cucumbers, melons, peppers, and strawberries. Acta Hort. 614:199-203.

Cantliffe, D.J., N.L. Shaw, E. Jovicich, J.C. Rodriguez, I. Secker, and Z. Karchi. 2001. Passive ventilated high-roof greenhouse production of vegetables in a humid, mild winter climate. Acta Hort. 559:195-201.

Cantliffe, D.J. and J.J. Vansickle. 2001. Competitiveness of the Spanish and Dutch greenhouse industries with the Florida fresh vegetable industry. Proc. Fla. State Hort. Soc. 114:283287.

Costa, J.M. and E. Heuvelink. 2000. Greenhouse horticulture in Almeria Spain: Report on a study tour 24-29 Jan. 2000. Horticultural Production Chains Group, Wageningen, the Netherlands.

Cotter, D.J. 1974. Yields of successive cropping of tomato in sawdust and bark media. HortScience 9:387-388.

Fukuda, N. and Y. Anami. 2002. Substrate and nutrient level: Effects on the growth and yield of melon 'Cucumis Melo' in soilless culture. Acta Hort. 588:111-117.

Garzo, E., C. Soria, M.L. Gomez-Guillamon, and A. Fereres. 2002. Feeding behavior of Aphis gossypii on resistant accessions of different melon genotypes Cucumis melo. Phytoparasitica 30:129-140.

Grillas, S., M. Lucas, E. Bardopoulou, S. Sarafopoulos, and M. Voulgari. 2001. Perlite based soilless culture systems: Current commercial applications and prospects. Acta Hort. 548:105-114

Gruda, N., C. Sippel, and W.H. Schnitzler. 2001. Evaluation of substrates for soilless culture and their properties: Investigation of physical properties of wood fiber substrates under press pot conditions. Acta Hort. 554:51-59.

Guler, H.G., C. Olympios, and D. Gerasopoulos. 1995. The effect of the substrate on the fruit quality of hydroponically grown melons $\mathrm{Cucu}$ mis melo L. Acta Hort. 379:261-266.

Gullino, M.L. and A. Garibaldi. 1994. Influence of soilless cultivation on soilborne diseases. Acta Hort. 361:341-353.

Hassall and Associates Ltd. 2001. Hydroponics as an agricultural production system. Rural Industries Research and Development Corporation. Publication no. 01/141. RIRDC, Kingston, Australia. $82 \mathrm{p}$

Hecht, D. 1998. Melon cultivation. Ministry of Agriculture and Rural Development, State of Israel.

Hochmuth, R.C., L.L. Leon, and G.J. Hochmuth. 1998. Evaluation of standard and specialty melon cultivars for North Florida. Univ. of Fla. Ext. Rep. 98-14. NFREC.

Jensen, M.H. 1997. Hydroponics. HortScience 32:1018-1021.

Jensen, M.H. 1999. Greenhouse hydroponic industry status reports: Hydroponics worldwide. Acta Hort. 481:719-729.

Kim, H.J. and Y.K. Kim. 2002. The effect of irrigation regime by integrated solar radiation on the growth pattern of muskmelon fruit in perlite culture. J. Kor. Soc. Hort. Sci. 43:255260

Louvet, J. 1982. The relationship between substrates and plant diseases. Acta Hort. 126:147152.

Maloupa, E., A.A. Hadid, M. Prasad, and C. Kavafakis. 2001. Response of cucumber and tomato plants to different substrates mixtures of pumice in substrate culture. Acta Hort. 559:593-599.

McGrady, J.J. and D.J. Cotter. 1989. Fresh conifer bark reduces root-knot nematode galling of greenhouse tomatoes. HortScience 24:973-975.

Michel, J.C., M.N. Bellon-Fontaine, and L.M. Rivière. 1999. Characterization of the wettability of organic substrates peat and composted bark by adsorption measurements. Acta Hort. 481:129-136. 
NeSmith, D.S. and J.R. Duval. 1998. The effect of container size. Hortechnology 8(4):495-498.

Orozco, R., O. Marfa, and S. Burés. 1995. Water status of graded perlites. Acta Hort. 401:137143.

Pardossi, A., P. Giacomet, F. Malorgio, F. Albini, C. Murelli, G. Serra, P. Vernieri, and F. Tognoni. 2000. The influence of growing season on fruit yield and quality of greenhouse melon Cucumis melo L. grown in nutrient film technique in a Mediterranean climate. J. Hort. Sci. Biotechnol. 75:488-493.

Pardossi, A., S. Landi, F. Malorgio, M. Ceccatelli, F. Tognoni, and C.A. Campiotti. 1994. Studies on melon grown with NFT. Acta Hort. 361:186-193.

Pardossi, A., F. Malorgio, C. Campiotti, and F. Tognoni. 2002. A comparison between two methods to control nutrient delivery to greenhouse melons grown in recirculating nutrient solution culture. Sci. Hort. 92:82-95.

Politycka, B., D. Wójcik-Wojtkowiak, and T. Pudelski. 1985. Phenolic compounds as a cause of phytotoxicity in greenhouse substrates repeatedly used in cucumber growing. Acta Hort. 156:89-94.

Raja Harun, R.M., D.A. Hall, R.A.K. Szmidt, and G.M. Hitchon. 1991. Melon cultivation in organic and inorganic substrates. Acta Hort. 294:105-108.

Reed, D.W. (ed.). 1996. Growing media: Types and physical/chemical properties, p. 93-122. In: Water media and nutrition for greenhouse crops. Ball Publishing, Batavia, Ill. p. 93-122.
Riviere, L.M. and J. Caron. 2001. Research on substrates: State of the art and need for the coming 10 years. Acta Hort. 548:29-41.

Schiavi, M., A. Venezia, D. Casarotti, and G. Martignon. 1995. Muskmelon cultivation on substrates. Acta Hort. 401:265-272.

Schnitzler, W.H. and H. Heuberger. 2001. Greenhouse bell pepper cultivation in low cost hydroponic systems. Acta Hort. 548:43-49.

Schröder, F.G. 1999. Alternative vegetables grown in hydroponic systems. Acta Hort. 481:213220.

Schwarz, M. 1995. Soilless culture management. Springer-Verlag, New York.

Segura, M.L., C. Cadahia, M. Abad, and A. Lopez. 1998. Fertigation of a melon crop grown in black sedge peat-based soilless media under saline conditions. Acta Hort. 458:369-377.

Shaw, N.L., D.J. Cantliffe, J. Funes, and C. Shine III. 2004a. Successful Beit Alpha cucumber production in the greenhouse using pine bark as an alternative soilless media. Horttechnology 14:289-294.

Shaw, N.L., D.J. Cantliffe, J.C. Rodriguez, and C. Shine, III. 2004b. Economic feasibility of producing Galia muskmelons in passive ventilated greenhouses and soilless culture in North Central Florida. Proc. Fla. State Hort. Soc. 117:38-42.

Shaw, N.L., D.J. Cantliffe, J.C. Rodriguez, S. Taylor, and D. Spencer. 2000. Beit Alpha cucumber and exciting new greenhouse crop. Proc. Fla. State Hort. Soc. 113:247-253.

Shaw, N.L., D.J. Cantliffe, and B.S. Taylor. 2001. Hydroponically produced Galia muskmelon:
What's the secret? Proc. Fla. State Hort. Soc. 114:288-293.

Starck, J.R. and W. Oswiecimski. 1985. Pine bark compost, peat and brown coal as substrates for greenhouse tomatoes. Acta Hort. 172:175182.

Tyson, R.V., R.C. Hochmuth, E.E. Lamb, G.H. Hochmuth, and M.S. Sweat. 2001. A decade of change in Florida's greenhouse vegetable industry: 1991-2001. Proc. Fla. State Hort. Soc. 113:280-282.

Verdonk, O. 1983. New developments in the use of graded perlite in horticultural substrates. Acta Hort. 150:575-581.

Waldo, E.A., G.J. Hochmuth, D.J. Cantliffe, and S.A. Sargent. 1998. Growing 'Galia' muskmelons using walk-in tunnels and a soilless culture system in Florida and the economic feasibility of using these systems. Proc. Fla. State Hort. Soc. 111:62-69.

Waldo, E. 1999. Out-of-season production of 'Galia' muskmelons in northern Florida using protective structures and soilless culture is technically and economically feasible. MS Thesis, University of Florida. Gainesville, FL.

Wilson, G.C.S. 1984. Tomato production in bark substrates. Acta Hort. 150:271-276.

Wilson, S.B., P.J. Stoffella, and L.A. Krumfolz. 2001. Containerized perennials make good use of compost. Biocycle 42:59-61.

Worrall, R.J. 1978. The use of composted wood waste as a peat substitute. Acta Hort. 82:79-86. 